\title{
The Life Aquatic: Liquid Poetics and the Discourse of Friendship in The Faerie Queene
}

From Michel de Montaigne's essay "Of Friendship" to Jacques Derrida's rearticulation of the former in The Politics of Friendship, scholars both early modern and modern have sought ways to address the fluid co-mixture of bodies from which the discourse of friendship can and does emerge. More recently still, new materialist thinkers of ontology have begun to shift our attention to the ways both human and nonhuman bodies inter-animate in the making of political, interpersonal, and artistic life worlds. Together with these investigations, I argue that an aquacentric account of relation is necessary to think the subject of friendship in Spenser's epic. Beginning with Spenser's queer address to Ralegh in Book III of The Faerie Queene and continuing through Book IV, I argue that Spenser reimagines the discourse of friendship in terms of a liquid, transcorporeal poetics, one that not only takes to its logical extreme humoral descriptions of bodies as conduits for liquids and passions but also importantly reworks human-exceptionalist readings of ontology in Spenser's epic.

Spenser Studies: A Renaissance Poetry Annual, Volume XXX, Copyright (C) 2015 AMS Press, Inc. All rights reserved.

DOI: $10.7756 /$ spst.030.000.00-00 
So to the sea we came; the sea? that is

A world of waters...

$\ldots$ and in those wandring stremes

Seek waies vnknowne.

-Edmund Spenser ${ }^{1}$

$\int \begin{aligned} & \text { ear the end of Book IV of The Faerie Queene, Edmund Spenser } \\ & \text { writes: }\end{aligned}$

O What an endlesse worke haue I in hand,

To count the seas abundant progeny,

Whose fruitfull seede farre passeth those in land,

And also those which wonne in thazure sky? (IV.12.1) ${ }^{2}$

A modesty topos, to be sure: Spenser, having just recounted the "seas abundant progeny" in the previous canto, in what is without doubt a bravura performance of the poet's genealogical cum thalassological knowledge and poetic mastery, begins Canto 12 less as a mariner in command of the "seas abundant progeny" and more as a courtier and lover avowing his shortcomings before the sea's inimitable "seede." The "fruitfull seede" that most confounds Spenser's numerical qua metrical "count," both here and elsewhere (as we shall soon see), is, of course, Venus, both goddess of beauty and fertility and figure for the errant sexuality of the seas:

That Venus of the fomy sea was bred;

For that the seas by her are most augmented.

Witnesse thexceeding fry, which there are fed,

And wonderous sholes, which may of none be red.

Then blame me not, if I haue err'd in count

Of Gods, of Nymphs, of riuer yet vnred:

For though their numbers do much more surmount,

Yet all those same were there, which erst I did recount. (IV.12.2)

Venus, figure of life-giving fertility, of the sea's autoerotic excess, disturbs Spenser's numerical "count," and so also, for a moment, interrupts the measure or metric of his poetic rendering, exposing the errancy ("err'd") internal to both the life represented (in this case, the sea) and Spenser's own poetic making. Venus augments the seas ("the seas by her are most aug- 
mented"), meaning that she multiplies, grows, swells (the Latin augmentare means "to increase") the already "abundant" oceans, "th'exceeding fry," and the "wonderous sholes," which, being too many, "may of none be red." Venus is a figure of love en abyme - a marine love which, as Roland Barthes reminds us in his lover's taxonomy, A Lover's Discourse, most represents "a craving to be engulfed" (s'abimer). "The crisis of engulfment," Barthes writes, "can come from a wound, but also from a fusion: we die together from loving each other: an open death, by dilution."

The sea-swellings that Venus represents in Spenser's The Faerie Queene share this double-edged meaning, which Barthes finds emblematized in the lover's outburst (translated from Goethe): "I am engulfed, I succumb." Venus multiplies life, but she also exceeds it ("their numbers do much more surmount"). If Spenser's stated goal in The Faerie Queene is to fulfill the rota Virgilii by abandoning pastoral life in favor of the martial, imperial, and territorial thematics of epic, as announced in the first lines of his poem, "For trumpets sterne to chaunge mine Oaten reeds," then it is the fluid, dilute, and engulfing power of Venus, figure not only of the abyss but of a sexuality that is itself abyssal, that threatens to turn Spenser's poem away from the war-machine of epic to the erring-desiring-machine of romance-a non-totalizable assemblage in which every part melts (yes, melts, we will return to this word later) with desire: "Gods ... nymphs ... riuer[s] yet vnred" (IV.12.2).

The following essay embarks upon two questions concerning friendship in Spenser's The Faerie Queene. The first question asks: what propinquity of desire links amity to the sea, such that, to invoke Foucault, friendship (amicitas, or, in a related sense, amare, "to love") becomes a way of life in Spenser's allegory? And second: whence this way of life such that it undoes the very category of "the human," indeed of the self-same human (homo) whose face, Foucault suggests, may someday "be erased, like a face drawn in sand at the edge of the sea"? ${ }^{4}$

In recent decades, early modern scholars' engagements with the history of sexuality have shifted attention to the somaticized and highly affective zones of encounter between friends, making the discourse of friendship a key point of study in early modern accounts of the body, queer sexuality, philology, and political structure. ${ }^{5}$ A central feature of nearly all of this work has been a greater attention to crossings and exchanges-to what Jeffrey Masten describes as the "interchangeability and absolute likeness of friends." ${ }^{6}$ Despite bridging older divisions within the history of sexuality, however, many of these studies retain a prior division, one that separates the 
domain of culture from that of nature and confines critical work to studying cultural production and the forms of communication it makes possible. Thus, when Masten describes the literal interchangeability of male friends in terms of "the fungible, humoral body, a conduit for liquids, humors, passions, and so forth," this liquid body remains wholly human-a site of philological and cultural investigation separate from the natural world. ${ }^{7}$ In the wake of ecocriticism and posthumanist theories of the body, however, this separation is increasingly untenable and in recent years scholars have produced work that not only trespasses cultural divisions but also that of culture from nature. ${ }^{8}$ Following this renaturalizing trend, ${ }^{9}$ my goal in this essay is to bring together early modern studies, ecocritical studies, and the history of sexuality so as to think through Foucault's admonition to treat friendship not as a process of discovery or mutual recognition but rather as a way of life-that is, a rethinking of how we define and value "life" itself.

From Michel de Montaigne's essay "Of Friendship" to Jacques Derrida’s rearticulation of the former in The Politics of Friendship, scholars both early modern and modern have sought ways to address the fluid co-mixture of bodies from which the discourse of friendship can and does emerge. More recently still, new materialist thinkers of ontology have begun to shift our attention to the ways both human and nonhuman bodies inter-animate in the making of political, interpersonal, and artistic life worlds. ${ }^{10}$ Together with these investigations, I argue that an aquacentric account of relation is necessary to think the subject of friendship in Spenser's epic. ${ }^{11}$ Beginning with Spenser's queer address to Ralegh in Book III of The Faerie Queene and continuing through Book IV, I argue that Spenser reimagines the discourse of friendship in terms of a liquid, transcorporeal poetics, one that not only takes to its logical extreme Masten's description of bodies as "conduits for liquids, humors, [and] passions" but also importantly reworks human-exceptionalist readings of ontology in Spenser's epic.

The first section develops my understanding of Spenser's liquid poetics, focusing in particular on the framing technologies, such as "Venus looking glas," that magnify and make tangible love's immaterial "seede" (III.1.8). Following recent scholarly investigations into the ways that specifically Lucretian materiality appears in English Renaissance texts, ${ }^{12}$ I read Spenser's poetics as a way of magnifying the aleatory movements of atoms, which Lucretius calls "seed." My claim is that the aleatory movement of atoms, of matter imperceptible to human sight, gains visibility in Spenser's poem predominantly in the form of liquid and erotic conjunctions: of bodies that "melt" with desire and therefore challenge definitions of hu- 
man being as solid or stable. From there I examine Britomart's benthic imaginary in Book III as a precursor to the liquid and lithic love figured around Marinell and Florimell in the Legend of Friendship. Whereas most critics tend to read Spenserian ontology as merely allegorical, I argue that in the case of friendship, the liquid bodies made fungible by early modern vocabularies, affects and desires are not strictly speaking bounded human bodies: Spenser's liquid poetics foregrounds bodies made richer and stranger by co-mingling with rivers, waters, and other sea-like bodies. His is an aesthetics open to the hospitality of a difference within the self; his waters know no boundaries.

\section{Liquid Poetics}

In Book III of The Faerie Queene, Spenser makes of Elizabeth's chastity a spur for reflecting on the matter of poetic making. He states:

It falls me here to write of Chastity,

The fayrest vertue, far aboue the rest;

For which what needes me fetch from Faery

Forreine ensamples, it to haue exprest?

Sith it is shrined in my Soueraines brest. (III.Proem.1)

In order to represent chastity, Spenser must represent the inner life of the queen, the inner temple or sanctum of her heart. And yet, this task of mimesis is itself impossible. As Spenser goes on, he acknowledges that "so liuely in each perfect part" is his sovereign's heart that neither "liuing art . . . / Nor life-resembling pencill it can paynt":

All were it Zeuxis or Praxiteles:

His dædale hand would faile, and greatly faynt,

And her perfections with his error taynt:

Ne Poets witt, that passeth Painter farre

In picturing the parts of beauty daynt,

So hard a workemanship aduenture darre,

For fear through want of words her excellence to marre.

(III.Proem.2) 
Neither the painter's "dædale hand" nor the poet's "witt" can represent the queen's inner "perfections," for the "pourtrait of her hart" exceeds any "liuing art." What is noteworthy, however, is that the failure to fit matter and meaning does not end in allegorical violence, as Gordon Teskey's theory of allegory would suggest, ${ }^{13}$ but rather makes of Spenser's allegory a tool for magnifying and thus visualizing nonhuman modes of self-fashioning.

Take the word "marre," for example. A word steeped in polyvalent and diachronic meanings (among them, notably, to impair, to ruin-as Spenser writes in Book III: "And striuing, fit to make, I feare doe marre" [III.2.3]), "marre" doubles as a shibboleth for the agency and transcorporeality of the sea. From the Old English mere and the Middle English marre, as well as post-classical Latin mare, we gather from this etymological stew an alternative account of what it means to "marre" the queen. Writing in reference to his friend Ralegh, whose pseudonym "Ocean" provides the material and semantic substrate of Spenser's liquefacient verse, Spenser characterizes the act of marring as a kind of bodily "melting":

But if in liuing colours, and right hew,

Thy selfe thou couet to see pictured,

Who can it doe more liuely, or more trew,

Then that sweete verse, with Nectar sprinckeled,

In which a gracious seruaunt pictured

His Cynthia, his heauens fayrest light?

That with his melting sweetnes rauished,

And with the wonder of her beames bright,

My sences lulled are in slomber of delight. (III.Proem.4)

In Spenser's poem, the liquid dynamics of male-male friendship detailed by Masten ebb and flow in relation to the paradox of Elizabeth's "chaste" pleasure, a pleasure portrayed by Ralegh not as singular, chaste, or inviolable virginity but as "melting sweetnes." Ralegh not only welcomes the oceanic feeling of bodies melting into other bodies, he turns the mirror of narcissistic indifference against itself, revealing not just the specularized Other of the masculine epic subject but the otherness internal to all subject "positions." In Ralegh's hands, the marine love (mare) that threatened to "marre" Spenser's poetic count not once, but twice, returns in the image of Elizabeth qua Venus, figure of the errant sexuality of the seas.

By abandoning the poet's "humble quill" in favor of the refractive powers of the allegorist's oblique "mirrours," Spenser transforms the 
narcissistic self-assertion of epic conquest to the recursivity and reconciliation of friendship. In mirroring Ralegh (who mirrors the queen), Spenser himself performs such a mis-en-abyme and exhorts his queen to do the same, and therefore to recognize the instability and porousness of her own sovereign subjectivity: "Ne let his fayrest Cynthia refuse, / In mirrours more then one her selfe to see" (III.Proem.5).

In the Letter to Ralegh, Spenser acknowledges that many readers will find "displeasaunt" his "Methode" of using "Allegoricall devices," which are "clowdily enwrapped" at best. ${ }^{14}$ In the lines above, however, he signals an alternative definition whereby the very artifice of allegory, understood technically as a play of mirrors, enables him to render the queen "in liuing colours, and right hew." The paradox is that this "liuing art" is in fact the product of an inhuman apparatus. The poem, figured as a kind of mirror, makes visible a life inaccessible to human sight. Spenser cannot represent the queen's inner virtue, but an apparatus such as allegory provides the optical illusion necessary to create a living poetry, one "clowdily enwrapped"- and therefore one that enacts at the level of form the pleasures as well as the frustrations of "clowdily" defined subjective and ontological borders.

Daniel Tiffany describes this conjunction between poetic iconography and scientific apparatus as being the very crux of "philosophical materialism," from Democritus's atom through the history of modern science, wherein "inquiries into the nature of material substance rely fundamentally on images that do not bear witness to empirical entities, but rather serve as models of unobservable phenomena." ${ }^{15}$ For Tiffany, "the foundation of material substance is intelligible to us, and therefore appears to be real, only if we credit the imaginary pictures we have composed of it." ${ }^{16}$ Hence "the forms of mediation and imagination proper to . . poetry begin to resemble the tools and practices of science-especially, as in physics, when it is a question of depicting unobservable phenomena." ${ }^{17}$ Both science and poetry proceed by attributing corporeal qualities to events imperceptible to human sight. In this sense, the matter of scientific observation is never quite distinct from the matter of poetic fashioning.

Following Tiffany, I want to suggest that the verb "to marre," far from being an idle pun in my usage, speaks directly to the liquid dynamics oft visualized in Spenser's fashioning of virtuous subjects. In other words, by drawing our attention to the failure of his allegorical "Methode" to make vivid things inscrutable to human sight, Spenser not only embraces the pictorial powers of the scientific apparatus but also imagines his allegorical 
method as a tool for magnifying the capacity of friendship to reinvent "life" as we know it. As James Kuzner explains, "in Spenser's epic . . . friends respect and reinforce each other's boundaries but also disregard and dissolve them." 18 This tendency to dissolve individual boundaries surfaces in the following lines, wherein Spenser admonishes Cupid, "thou dred infant, Venus dearling doue," to "chase imperious feare" from "my soueraigne Queene" and "vse of awfull Maiestie remoue":

In sted thereof with drops of melting loue,

Deawd with ambrosiall kisses, by thee gotten

From thy sweete smyling mother from aboue,

Sprinckle her heart, and haughtie courage soften,

That she may hearke to loue, and reade this lesson often.

(IV.Proem.5)

Spenser imagines his ideal reader as one open to the "melting loue" that he previously attributes to Ralegh. Rather than halt his "magnifying" lens, he turns to Cupid, beckoning the latter to scatter ambrosial "drops" akin to Venus' "fruitfull seede," so that the image of love, being "fruitfull," can multiply. My interest here is in the way Spenser represents love: what do the fruition and multiplicity of his "Allegoricall devices" depict?

Reid Barbour notes that in early modern depictions of materiality, the atom was often eroticized: "Mythologized in the person of Cupid, the atom ... is made all the more complex insofar as atomic desire risks lust and anarchy." ${ }^{19}$ Francis Bacon, for example, "maintains that the ancients allegorized the properties of the atom in the nudity, archery, infancy, and blindness of Cupid." ${ }^{20}$ Lucretius no doubt provides precedent for this allegorical view: not only are his atoms blind, but Venus, mother of Cupid, is the muse of his poem. Spenser's invocation of Venus' "fruitfull seede" in Book IV shows a keen awareness of this allegorical interpretation of the atom. What's more, his emphasis on the instruments of visualization, making repeated reference to his own poem as a tool of magnification, as when Britomart, "wondrous glad," softens her martial demeanor at hearing "her Love so highly magnifyde" by Redcrosse's speech, begs us to think of Spenser's allegory in Tiffany's terms as a poetic apparatus, a tool capable of "giving life and 'passion' to insensible things" (III.2.11). ${ }^{21}$

Between the 1590 and 1596 editions of The Faerie Queene, the images of love's virtue do indeed multiply according to the refractive angle of Spenser's poetic apparatus: from the images of Cynthia, Gloriana, and 
Belphœbe in the Proem to Book III, to the image of Venus evoked by Britomart's "looking glas." Spenser's multiplication of life's images are as numerous as Venus' innumerable "seede"-and as volatile. For the "lust and anarchy" that Bacon discerns in the atom finds its expression in the "drops of melting loue" that Spenser twice attributes to poetic fashioning. If, in Spenser's hands, poetry is an instrument of magnification, then the insensible object of his gaze-atomic desire-appears most often and most powerfully as a kind of melting carried out allegorically as an erosion of bodily boundaries by liquid forces. To follow Kuzner's remarks above, it does not suffice to read Spenser's "open subjects" as always already human; for the power to practice non-sovereignty in relation to others-via friendship-is as much a power to co-assemble with inhuman forces. To imagine "open subjects," we need think not only of what it means to fail at self-fashioning- "to marre," as Spenser says; but also how such failure enables us to visualize a much broader cosmopolity beyond the strictly human community, to see, along with Foucault, the human face erased at the edge of the sea. ${ }^{22}$

In the following section, I examine the relationship between poetic iconography and material description through the particular lens of Britomart's benthic imagination. Dan Brayton usefully defines the "benthic imagination" in the context of Shakespeare studies as the figurative construction of human life as a sea voyage. The ocean according to Brayton serves as "(1) a mirror of human ontology, culture, and civilization; (2) the space of transit, an undomesticated boundary between realms, a threat to cosmic and social order; (3) the arena of providence; and (4) a transitional space between the supernatural and the protoscientific." ${ }^{23}$ Each of these definitions will come to bear on my reading of the Legend of Friendship, and of Marinell and Florimell in particular. For now, I turn to Britomart in Book III to show that the image of human life reflected by the sea not only mirrors human ontology, as Brayton suggests, but much more troublingly erodes and consumes that image, producing an oceanic subjectivity open to the pain and suffering of others. 


\section{BRITOMART's BENTHIC IMAGINARY}

Thus far I have argued that the focus on fashioning in Spenser's Faerie Queene can and should be read in terms of the technical apparatuses figured throughout the poem, which give to the reader's eye a semblance of events imperceptible to human sight. These semblances are neither static nor mimetic, for what they "represent" are not objects or things but rather happenings or becomings: from the Latin sembler, meaning to gather or assemble. Semblances visualize the movement of poetic making (poiesis) by making that very movement of creation the object of poetic sight. In so doing, they enable us "to see" bodies available only at the scale of the poetic apparatus-what Spenser calls his "Allegoricall devices" or "frame"-assembling and disassembling before our very eyes. Such shifts in scalefrom the imperceptible to the perceptible and back-result in disaggregating movements at the level of the human body, as the image of the human body begins to dissolve in relation to other assembled images, such as Spenser's "melting" in sensuous "delight" before the image of Ralegh's Cynthia.

In Book III, we see another such image, this time mixed not with the affect of "delight" but with the affect of "melancholy" and despair. Here, Britomart gazes upon a mirror fashioned by the "Magitien Merlin," whose "deepe science" produced a "looking glasse" capable of "shew[ing] in perfect sight / What euer thing was in the world contained" (III.2.18-19). Britomart sees in this "world of glas" the "semblant of a knight, / Whose shape or person yet [she] never saw," but whose image, she remarks, "Hath me subjected to loues cruell law" (III.2.19, 38):

The Damzell well did vew his Personage, And liked well, ne further fastned not, But went her way; ne her vnguilty age

Did weene, vnwares, that her vnlucky lot

Lay hidden in the bottome of the pot;

Of hurt vnwist most daunger doth redound:

But the false Archer, which that arrow shot

So slyly, that she did not feele the wound,

Did smyle full smoothly at her weetlesse wofull stound. 
And if that any drop of slombring rest

Did chaunce to still into her weary spright,

When feeble nature felt her self opprest,

Streight way with dreames, and with fantastick sight

Of dreadful things the same was put to flight,

That oft out of her bed she did astart,

As one with vew of ghastly feends affright:

Tho gan she to renew her former smart,

And thinke of that fayre visage, written in her hart. (III.2.26, 29)

At once an object of human "shape" and a figure of love's inscrutability, the "Personage" whom Britomart encounters in the "looking glas," far from being a mere representation of a knight, is best understood as a figure of conjunction. This figure is akin to the "melancholy assemblage," which, according to Drew Daniel, "joins together its sufferers and its witnesses into tenuous perceptual communities." 24 Britomart, "weetlesse" of Cupid's arrow, "thought it was not loue" which she suffered, "but some melancholy" (III.2.27). The "semblant" that enables her to see "her Loue ... magnifyde" also subjects her to the "tyranny" of that love, which is experienced as both internal compulsion and external force, and thereby questions the boundaries between inside and outside, self and other.

The joining of sufferer and witness that melancholy enables begins from the moment "fayre Britomart" looks into the "mirrhour playne." From this "did grow her first engraffed payne, / Whose root and stalke so bitter yet did taste" (III.2.17). The image itself entangles seer and seen, just as the language of vegetable love engrafts foreign bodies. Later the image of "engraffed payne" transforms into an image of writing, as Britomart turns her gaze inward "to renew her former smart, / And thinke of that fayre visage, written in her hart" (III.2.29). From the initial graft of "root and stalke" to its engraved repetition in Britomart's "hart," the image takes on the phantasmatic or dreamlike quality that again confounds the objective perception of external objects with internal, subjective experience. Shrouded by this image-world, this "Night," in which the "beautie of the shyning skye" is "Defaste," and "reft" is the "worldes desired vew," Britomart suffers "dreames" and "fantastick sight / Of dreadfull things ... As one with vew of ghastly feends affright" (III.2.28-29). Under "loues cruel law," Britomart's "liuely cheare" turns more "dead" than "liuing"; the negative obverse of Spenser's herbal metaphor, it loses "Both leafe and fruite, both too vntimely shed" (III.2.31). 
This assemblage of image-plant-heart that joins Britomart's melancholy to the wider ecological surround includes forms of relationality that go beyond the bounded subjectivity that would seem to ground Spenser's purported aim of fashioning persons of "vertuous and gentle discipline." Britomart's nurse, Glauce, for example, would seem the exemplary voice of such disciplinary measures. Reasoning with Britomart, Glauce urges Britomart not to be carried away by "despeire," since no love, no matter how "sore," is beyond the "salue" of reason (III.2.35). And yet Glauce, too, suffers melancholy's web of entangled relationality. Having just "auow[ed]" to "ease [Britomart's] griefe, And win [her] will" from the "knowen signes and passions" of love (III.2.33), Glauce undergoes the same melancholy transformation: "So hauing sayd, her twixt her armes twaine / Shee streightly straynd, and colled tenderly, / And euery trembling ioynt, and euery vaine / Shee softly felt, and rubbed busily" (III.2.34). This compassion-or fellow-feeling-has the effect of taking Britomart out of herself. Seeing her nurse thus tormented, Britomart exclaims: "Ah Nurse, what needeth thee to eke my paine? / Is not enough, that I alone doe dye, / But it must doubled bee with death of twaine?" (III.2.35). The reciprocal grief shared by Britomart and Glauce makes visible the joining of sufferer and witness that Daniel attributes to melancholy's involuntary processes of assembly. Yet while scholars such as Daniel and Gail Kern Paster often use images of fluidity to describe humoral fluctuations and assemblages, these liquid bodies are, in the end, always already human bodies. ${ }^{25}$

Britomart's melancholy resists this anthro-determinacy. What first reads as metaphor in the encounter with the mirror soon turns literal as Britomart, journeying to find her "semblant" knight and "Following the guydaunce of her blinded guest," Cupid, arrives at the "seacoast" (III.4.6). There she reactivates the memory of her inner scar- "her wound she fedd"-and "to the seacoast at length she her addrest." This self-consuming scar-Cupid's "shot" - "more grieuous bredd" (III.4.6), until inner grief and outer nature become mutually expressive:

Tho hauing vewd a while the surges hore, That gainst the craggy clifts did loudly rore, And in their raging surquedry disdayned, That the fast earth affronted them so sore, And their deuouring couetize restraynd, Thereat she sighed deepe, and after thus complayned. (III.4.7) 
Inner "deepe" and outer "deepe"-self-consuming "wound" and "earth"consuming "surges"- change places. The sea's "deuouring" currents not only mirror Britomart's "deep engord . . . hart" but also magnify and deterritorialize her physical body, remapping the topography of her "hart" away from the fixed body and the land's "craggy clifts" to the disassembling movements of the "sea ... and tempestuous griefe" (III.4.8). In Britomart's benthic imaginary, "deepe" echoes "deepe":

Huge sea of sorrow, and tempestuous griefe, Wherein my feeble barke is tossed long, Far from the hoped hauen of reliefe, Why doe thy cruel billowes beat so strong, And thy moyst mountaines each on others throng, Threatening to swallow vp my fearefull lyfe? O doe thy cruell wrath and spightfull wrong At length allay, and stint thy stormy stryfe, Which in thy troubled bowels raignes, and rageth ryfe.

For els my feeble vessell crazd, and crackt Through thy strong buffets and outrageous blowes, Cannot undure, but needes it must be wrackt On the rough rocks, or on the sandy shallowes, The whiles that loue it steres, and fortune rowes; Loue my lewd Pilott hath a restless minde And fortune Boteswaine no assuraunce knowes, But saile withouten starres, gainst tyde and winde: How can they other doe, sith both are bold and blinde? (III.4.8-9)

Here love and fortune take tangible form in the image of life at sea. More than just a metaphor for Britomart's inner "deepe," Spenser uses the Petrarchan image of a "feeble vessell crazd, and crackt" to illustrate the material linkage between love and the body's vulnerability. In so doing, "stormy stryfe" serves less as a reflection of human ontology than as an image of material and intertextual assembly. Britomart loses her fixed identity by dissolving into the sea; although temporary, this moment of dissolve showcases a fundamental lesson about Spenserian ontology: that persons-"shadow[s]" as Spenser calls them in the Letter to Ralegh-are as much a part of the world of material "Accidents" or events as they are separate from it. 
Britomart's benthic imaginary testifies to love's power to fashion oceanic subjects. However, the appearance of Marinell shortly after in Book III forces us to reckon with a subject whose fame as "loues enimy" runs contrary to the fluid co-mixture of bodies that I have been tracing (III.4.26). Marinell, as his name indicates, is the product of ontological crossing; a "Sea-nymphes sonne," Marinell is both human and inhuman: son of both man and nymph, grandson to Nereus, and heir to the "riches" of the "deepe" (III.4.22). Marinell, his mother Cymoent laments, is the very "image" of herself (III.4.36). And yet Marinell also brings to an abrupt conclusion Britomart's liquid reverie, shifting the optic of the poem from the dilute bodies made visible by melancholy to the martial and agonistic bodies that we see magnified by friendship in Book IV. Spenser renders this perceptual shift as a "mist" lifting from Britomart's visual field:

As when a foggy mist hath ouercast

The face of heuen, and the cleare ayre engroste,

The world in darkenes dwels, till that at last

The watry Southwinde from the seabord coste

Vpblowing, doth disperse the vapour lo'ste,

And pours it selfe forth in a stormy showre;

So the fayre Britomart hauing disclo'ste

Her clowdy care into a wrathfull stowre,

The mist of griefe dissolu'd, did into vengeance powre. (III.4.13)

After seeing "proud Marinell vpon the pretious shore," Britomart dissolves her "griefe," and with it the connection of her fragile "feeble vessell" to the foreign bodies to which she was "engraffed": plant, nurse, sea, and earth. The ensuing battle ends as abruptly as it began, with Marinell suffering a "mortall" wound, and Britomart continuing her journey without concern for the wounded: "The martiall Mayd stayd not him to lament" (III.4.17, 18). The epic assertion of bounded selfhood leaves no room for compassion.

We see in the case of Marinell that the defense of psychic as well as bodily boundaries reproduces the violence needed to maintain those boundaries. In this regard, Marinell allegorizes the paradox that self-protection-avoiding the vulnerability of love-requires an adversarial way of being that exposes one to more, not less, violence. Fearing Proteus's "prophecy" that "of a woman he should haue much ill," Marinell, at the behest of his mother, "euer from fayre Ladies loue did fly" so as to avoid the deep wounds that love can make (III.4.25-26). In this sense, Marinell, 
although rarely the focus of scholarly inquiry, best reveals the symptomatic logic of the friendship legend as one bent on fashioning virtuous subjects through violence. This self-defeating logic is exemplified by Marinell's mother, Cymoent, about whom Spenser states: "So weening to haue arm'd him, she did quite disarme" (III.4.27). Marinell's vulnerability makes clear that bounded subjects do not reduce the need for violence. On the contrary, Marinell's exposure to violence is a direct result of his opposition to love's enervating force. Whereas the former violence leads to death without community ("The martiall Mayd stayd not him to lament"), the latter gathers bodies together through a shared vulnerability and openness to others.

What makes Marinell's story so significant, then, is that he multiplies love's attachments by making the violence and vulnerability of love the basis for friendly community. Spenser imagines this form of violence as a kind of elemental fragility shared among individuals - both human and nonhuman-and so shifts the optic of his poem away from the seacoast locale of Britomart's benthic imaginary to the "seas abundant progeny," of which Marinell is one. Turning to Book IV, we find that the appearance of Marinell marks not so much the cessation of Britomart's benthic imaginary as its multiplication and refraction among friends.

\section{MARINELL AND THE LEGEND OF FRIENDSHIP}

In "Friendship as a Way of Life," Foucault argues that the problem of love (or homosexuality more specifically) "is not to discover in oneself the truth of one's sex, but, rather, to use one's sexuality henceforth to arrive at a multiplicity of relationships." To treat sexuality "not [as] a form of desire but [as] something desirable," Foucault suggests, means "to invent, from A to $\mathrm{Z}$, a relationship that is still formless, which is friendship." ${ }^{26}$ Although numerous critics have pointed to the often surprising overlaps and tensions between love and friendship in The Faerie Queene, ${ }^{27}$ I reference Foucault's definition of friendship in order to highlight a key aspect of Spenserian ontology that scholars have yet fully to remark upon: namely, the linkage in Spenser's poetry between love (amare) and the sea (mare) has consequences for all relationships in which acknowledgment of likeness (homo-geneity) overcomes difference and hierarchy (hetero-geneity). In the Legend of Friendship, we see the literalization of Foucault's idea of friendship as 
a "way of life" - whereby "life itself" becomes a type of wending, journeying, erring condition of human agency-in the marriage of two rivers. In Canto 11, Spenser turns his allegorical gaze to the Thames and the Medway rivers, for whom "all the Sea-gods and their fruitfull seede, / In honour of the spousalls," are gathered together (IV.11.8). Enacting the epithalamion genre's signature traits of sexual violence and heteronormativity, ${ }^{28}$ Spenser not only changes the sex of the Medway river, as noted by A. C. Hamilton, ${ }^{29}$ but also depicts a scene in which the "proud Nymph" "relent[s]" to the Thames's sexual advances:

Long had the Thames (as we in records reed)

Before that day her wooed to his bed;

But the proud Nymph would for no wordly meed,

Nor no entreatie to his loue be led;

Till now at last relenting, she to him was wed. (IV.11.8)

The Oxford English Dictionary defines "relent" as a type of bodily melting, from the Anglo-Norman word relenter, meaning "to melt, slacken, give up." Although in the fifteenth and sixteenth centuries "relent" could be used interchangeably to mean either "to relinquish or abandon a resolution or course of action" or "to dissolve into water," Spenser capitalizes on both meanings by portraying the marriage of the two rivers as a loss of will, a "relenting" on the part of the Nymph. While common enough within the genre of epithalamic poetry, the coercive nature of the rivers' union, whose sexual telos is signaled by the rhyming of "bed," "led," and "wed," serves here to remind the reader of Florimell's capture by Proteus in Book III and to prefigure the marriage between Florimell and Marinell in Book IV. Regarding the former, Proteus captures Florimell after having rescued her from the "Fishers wandring bote" (III.8.31). He then takes her to his underwater "bowre" deep "in the bottom of the maine," where he "make[s] him selfe a mortall wight," and "like a Faerie knight him selfe he drest; / For euery shape on him he could endew" (III.8.37, 39-41). Infinitely changeable, Proteus cannot, however, change Florimell's heart, since "Eternall thraldome was to her more liefe, / Then losse of chastitie, or chaunge of love" (III.8.42). Unable to win Florimell's affections through friendship, Proteus turns to violent force: "Down in a Dongeon deepe he let her fall, / And threatned there to make her his eternall thrall" (III.8.41).

Thus the marriage of the two rivers is not only a reminder of Florimell's capture by Proteus; more importantly, it is a recapitulation of the violence 
that Florimell endures over the course of two Books. The model of relationality thus allegorized by the two rivers is one in which domination and loss of will are essential to the instrumentalization of friendship for the purpose of marriage. No doubt it is for this reason that scholars keen on investigating the erotic impulses of Book III have little to say about Florimell and Marinell, who seem to conform all too well to C.S. Lewis's influential assertion that the direction of love in Spenser's allegory is the marriage bed. ${ }^{30}$ The Legend of Friendship binds the erotic excesses of Book III by fashioning subjects whose ultimate purpose is-so the story goes-to "relent" to the marriage plot.

And yet there is another possibility for reading the language of "relenting" in the Legend of Friendship. In this second reading, the rivers do not just prefigure the marriage of Florimell and Marinell; they represent the more-than-human possibilities for thinking friendship in Spenser's allegory. Just as we have seen Spenser "melt" in relation to Ralegh, and Britomart in relation to the sea, so the marriage of the Thames and Medway rivers enables us to imagine forms of relationality beyond the strictures of domination, utilization, and heteronormativity. Read literally (as Spenser's allegory no doubt invites us to do) "relenting" serves not only to connect Spenser's liquid poetics to the discourse of friendship but to multiply love's intensities in places where, in Foucault's words, "there is supposed to be only law, rule, or habit."

Consider Florimell's complaint at the end of Book IV. Imprisoned in Proteus's "dongeon deepe," and "bound" by "chaynes" (IV.11.2-3), Florimell provides the visual and topographic obverse of the wedding ceremony by literalizing —in "chaynes" - the rivers' "spousalls" bonds:

Yet loe the seas I see by often beating,

Doe pearce the rockes, and hardest marble weares;

But his hard rocky hart for no entreating

Will yeeld, but when my piteous plaints he heares,

Is hardned more with my aboundant teares.

Yet though he neuer list to me relent,

But let me waste in woe my wretched yeares,

Yet will I neuer of my loue repent,

But ioy that for his sake I suffer imprisonment. (IV.12.7)

At its extreme, Spenser suggests, the fashioning of virtue through friendship leads to bondage and imprisonment; for Florimell, however, more 
disconcerting than Proteus's stony prison is the imprisonment she suffers due to Marinell's "rocky hart," to which "no entreating / Will yeeld," and which, unlike "marble" or "stone," not even the "seas" rough "beating" can "pearce." For Florimell, love is a prison, "So had [she] rather to be thrall, then free" (IV.12.10). Echoing Britomart's complaint in Book III, Florimell draws a negative comparison between Marinell's "rocky hart" and the rock that confines her, stating that whereas the latter yields in time to the heaving of the sea, Marinell, by contrast, "when my piteous plaints he heares / Is hardned more with my aboundant teares." An imaginary more lithic than benthic, Florimell contrasts love's oceanic bodies (her own) with the mineralized and militarized bodies of epic. And yet, what appears at first as antinomy soon gives way to bodily mingling as the stone that surrounds Florimell "relents" to her "lamentable voice":

So feeling her case she did complaine,

That ruth it moued in the rocky stone,

And made it seeme to feele her grieuous paine,

And oft to grone with billowes beating from the maine. (IV.12.5)

From stone that confines to stone that moves in fellow feeling for its captive's "greuious paine," Florimell's Orphic song imagines a lithic love in which "rocky stone" relents-that is, dissolves-becoming more lively by sharing in Florimell's pain. By entering into sympathetic union with Florimell, the stone becomes a thrall to her emotion, but one with more animation and agency than those, like Marinell, who fashion "rocky hart[s]." ${ }^{11}$ Hence Florimell's paradox: "Such thraldome or such freedome." To be a thrall to love is to be free; Florimell shares this e-motional freedom, "or" this bondage, with the elements of rock and sea.

When Marinell hears Florimell's complaint, he too "relent[s]":

All which complaint when Marinell had heard, And vnderstood the cause of all her care

To come of him, for vsing her so hard, His stubborne heart, that neuer felt misfare Was toucht with soft remorse and pitty rare; That euen for griefe of minde he oft did grone, 
Thus whilst his stony heart with tender ruth

Was toucht, and mighty courage mollifide,

Dame Venus sonne that tameth stubbore youth

With iron bit, and maketh him abide,

Till like a victor on his backe he ride,

Into his mouth his maystring briddle threw,

That made him stoupe, till he did him bestride:

Then gan he make him tread his steps anew,

And learne to loue, by learning louer paines to rew. (IV.12.12-13)

Recalling the ecological assemblage of image-plant-heart that grafts Britomart's melancholy to Guyon and Glauce, and later the sea, Marinell's encounter with Florimell's voice brings him into sympathetic union with the elements: his "stony heart" was with "tender ruth / . . toucht"; it "moued" in unison with the "rocky stone." And like the stone that cries out "with billows beating," he too "for griefe of minde . . . did grone." For the first time in Marinell's journey, he experiences pain without purpose of utility; his "ruth" is not secondary to the pains of self-fashioning but rather integral to the unbounded being that he is (becoming). Marinell becomes a thrall to love, so much so that he too appears bound and bridled by "Venus sonne." This inhuman assemblage of voice-rock-sea-and-horse shifts the optic of Spenser's allegory away from the bounded body of (human) self-fashioning toward a different understanding of the homo: for with Marinell, it is the relation of difference and sameness indicated by his very name (Marinell is a composite of both masculine and feminine nouns-marin, marineand land and sea, since marine refers to tidelands) that links his capacity to feel pain to the elements that pass through him, which are not exterior but rather animate his every movement. In Spenser's hands, this sense of homo-ness-of being composed by the same matter as rock and sea that goes beyond man (homo) toward intimacy with inhuman beings suggests a different kind of friendship, one at odds with the regulatory norms of a marriage plot premised on sexual difference, conquest, and hierarchy.

Tamed by "Venus sonne," Marinell succumbs to "louers paines" and to a melancholy that consumes his every thought: "In solitary silence far from wight, / He gan record the lamentable stowre, / In which his wretched loue lay day and night, / For his deare sake that ill deseru'd that plight" (IV.12.19). Like Britomart before him, Marinell "record[s]" his melancholy by engraving Florimell's memory directly on his heart: "The thought whereof empierst his hart so deepe, / That of no worldly thing he tooke delight; / 
Ne dayly food did take, ne nightly sleepe, / But payn'd, and mourn'd, and languisht, and alone did weepe" (IV.12.19). Alone, consumed by melancholy, the Marinell we see in Book IV is the semblance of the knight whom Britomart left alone on the beach, friendless and without care, but with the following difference: when Cymoent sees her son Marinell, "vnable once to stirre or moue," she at first rebukes the sea-god Tryphon for failing to heal his "former fatall wound," and seeks a final cure for his "new languishment" (IV.12.23). When no cure can be found for the "loue" that "afflict[s] his engrieued mind," she too relents (IV.12.25). By rejecting Proteus's prophecy, which ruled against love, Cymoent becomes a friend to her son not despite their shared affliction but because of it; in so doing, she makes of friendship a means for maximizing, not abstaining from, the most intense and corporeal experience of love as a shattering of boundaries:

That Florimell it was, which wrought his paine, She gan a fresh to chafe, and grieue in euery vaine.

Yet since she saw the streight extremitie,

In which his life vnluckily was layd, It was no time to scan the prophecie, Whether old Proteus true or false had sayd, That his decay should happen by a mayd.

It's late in death of daunger to aduize, Or loue forbid him, that is life denayd:

But rather gan in troubled mind deuize, How she that Ladies libertie might enterprize. (IV.12.27-28)

The "libertie" to love Marinell made Florimell a prisoner to Proteus's desire; hearing this, both Marinell and Cymoent become thralls to this "mayd" whose affliction they share: "Or loue forbid him, that is life denayd" (IV.12.28). The "life denayd" to Marinell is not only his mortal life but also Florimell's; his "extremitie" is her imprisonment.

But the "relenting" that we see between Florimell, Marinell, and Cymoent is altogether different from the "relenting" prescribed by Proteus, who understands friendship as a means of giving way on one's desires, whether through discipline or through violent coercion. By contrast, the "relenting" that Cymoent undergoes for her son and for Florimell at the end of Book IV is more like the "drops of melting love" that Spenser describes in reference to Elizabeth, namely, an anonymous and involuntary state of being 
dissolved through non-mastery. Just as the anonymous elements of stone and sea move with pity, so Cymoent, whose provenance is the sea, moves with e-motion for the "mayd" whose suffering she shares. Such voluntary relinquishment of the autonomy and self-determination celebrated by epic rests on a shared vulnerability in which boundaries are not so much overcome as recognized as permeable and phantasmatic from the beginning.

This version of friendship, in which one individual relents to another not by sacrificing one's will but by sacrificing one's wish for autonomy, runs counter to the Friendship Legend's previous episodes where the body's inhuman composition is cordoned off by the imperative to fashion impenetrable subjects. Consider the following scene of martial combat in which the collision of warlike bodies produces an ecological milieu at once coextensive with the bodies rendered and separate:

As when two billowes in the Irish sowndes,

Forcibly driuen with contrarie tydes,

Do meete together, each abacke rebowndes

With roaring rage; and dashing on all sides,

That filleth all the sea with fome, diuydes

The doubtfull current into diuers wayes:

So fell those two in spight of both their prydes,

But Scudamour himself did soon vprayse,

And mounting light his foe for lying long vpbrayes. (IV.1.42)

When Paridell attacks Scudamour, he does so out "of friendship" for Blandamour, who reasons: "That as I late aduentured for your sake, / The hurts whereof me now from battell stay, / Ye will me now with like good turne repay" (IV.1.40). In the friendship economy defined by Blandamour, friends assume "hurts" only if it is profitable to do so based on their individual interests. As bounded individuals, Blandamour and Paridell agree to risk their autonomy so as to establish greater autonomy through the unequal distribution of bodily suffering. Consequently, when Paridell "of friendship" competes with Scudamour, they do so as "two billowes" moving with "contrarie tydes," who with "roaring rage ... diuydes / The doubtfull current into diuers wayes." Although Spenser once again shifts the optic of his poem to visualize friendship in a nonhuman register, he does so from the vantage of an oblique simile: "As when." The distance surmounted by Spenser simile-between human events on the one hand, and nonhuman events on the other-remains the focus of the analogy, such that we 
are meant to recognize the divisions between self and sea ("the sea with fome, diuydes") over and above their continuities. These knights whose "prydes" multiply their injuries remain too prideful to relent to each other's suffering.

Cymoent, by contrast, does not give way on her desires only to further her self interest; nor does she prize greater autonomy as the telos of friendship. Instead, Cymoent lets herself be undone by her affections; she relents to an internal force that seeks amity rather than enmity. Like the suffering shared between Britomart and the sea, and Florimell and the "rocky stone," Cymoent melts with fellow-feeling. When we reach the end of the Friendship Legend, this mutuality of feeling, or this indifference to the other's difference, crosses the ontological boundaries between nymph and mortal "wight" to enfold all three:

Right so himselfe did Marinell vpreare,

When he in place his dearest loue did spy,

And though his limbs could not his bodie beare,

Ne former strength returne so suddenly,

Yet chearefull signes he shewed outwardly.

Ne less was she in secret hart affected. (IV.12.35)

When Marinell rises to meet Florimell, "though his limbs could not his bodie beare," we read that he does so like a plant: Marinell turns to his friend, "As withered weed through cruell winters tine, / That feeles the warmth of sunny beames reflection, / Liftes vp his head, that did before decline / And gins to spread his leafe before the faire sunshine" (IV.12.34). Here the distance travelled by Spenser's simile is not called into question by warring subjects. Instead, Spenser invites us to read Marinell's "chearefull signes" materially, heliotropically, and errantly-as signs of life.

If, as I have argued above, scholars of early modern sexuality have tended to neglect Marinell and Florimell due to their supposed predictability and conventionality in comparison with the amorous "play" of Book III, then what I wish to underscore here is just how counterintuitive and unpredictable is a marriage that collates the diverse materialities of humannymph-rock-plant-and-sea. Unlike the marriage between the two rivers, which turns gendered difference into a loss of will, and unlike the battle between Paridell and Scudamour, which instrumentalizes friendship for personal gain, the concord achieved between Marinell and Florimell is conventional only in the most capacious sense of the word convention: a 
concordance structurally shared by all. The friendship that we witness at the end of the Book IV between Marinell and Florimell is as much hetero as it is homo, in Foucault's sense. And that is because the entanglements wrought by love, far from abating after Book III, proliferate along vectors of friendship that link what is hetero-self versus other-to a much denser, more perverse fabric of life and materiality.

Spenser's liquid poetics thus enables us to read signs like "relent" both doubly and materially: not just as an expression of a Protestant morality aimed at fashioning proper subjects; but as a literal manifestation of the fragility "we" share with inhuman ecologies. In Spenser's liquid poetics, signs such as Marinell's are best read athwart of human ontology, as vital signs; they are as innumerable, and as errant, as the sea's abundant seed.

\section{Brown University}

\section{Notes}

1 Edmund Spenser, Colin Clovts Come Home Againe, in The Shorter Poems, ed. Richard A. McCabe (London: Penguin Books, 1999), 350.

2 All quotations from The Faerie Queene (book, canto, and stanza) are taken from Edmund Spenser, The Faerie Queene, ed. A. C. Hamilton, 2nd ed. (London: Longman, 2007).

3 Roland Barthes, A Lover's Discourse: Fragments, trans. Richard Howard (New York: Hill and Wang, 1978), 10, 10-11.

4 Michel Foucault, The Order of Things: An Archaeology of the Human Sciences, trans. Alan Sheridan (New York: Vintage, 1994), 387. See also Foucault, "Friendship as a Way of Life" in Ethics: Subjectivity and Truth, trans. Robert Hurley, ed. Paul Rabinow (New York: The New Press, 1997).

5 See esp. Alan Bray, The Friend (Chicago: University of Chicago Press, 2003); Jeffrey Masten, Textual Intercourse: Collaboration, Authorship, and Sexualities in Renaissance Drama (Cambridge: Cambridge University Press, 1997); Laurie Shannon, Sovereign Amity: Figures of Friendship in Shakespearean Contexts (Chicago: University of Chicago Press, 2002); Alan Stewart, Close Readers: Humanism and Sodomy in Early Modern England (Princeton: Princeton University Press, 1997); and Valerie Traub, The Renaissance of Lesbianism in Early Modern England (Cambridge: Cambridge University Press, 2002). 
6 Jeffrey Masten, “Toward A Queer Address: The Taste of Letters and Early Modern Male Friendship," GLQ: A Journal of Lesbian and Gay Studies 10.3 (2004): 371.

7 Masten, “Toward A Queer Address," 376.

8 Among early modern ecocritical accounts, see Vin Nardizzi, Wooden Os: Shakespeare's Theatres and England's Trees (Toronto: University of Toronto Press, 2013); and Laurie Shannon, The Accommodated Animal: Cosmopolity in Shakespearean Locales (Chicago: University of Chicago Press, 2013). See also Gail Kern Paster's influential study of the humoral body's co-composition with the environment in Humoring the Body: Emotion and the Shakespearean Stage (Chicago: University of Chicago Press, 2004).

9 I borrow the term "renaturalization" from political theorist Hasana Sharp, who develops "a politics of renaturalization from Spinoza's naturalism." See Sharp, Spinoza and the Politics of Renaturalization (Chicago: University of Chicago Press, 2011), 2.

10 My account of Spenser's liquid ontology draws on the new materialism of Stacy Alaimo. See Alaimo, Bodily Natures: Science, Environment, and the Material Self (Bloomington: Indiana University Press, 2010).

11 In making this aquacentric argument, I draw on the recent "oceanic turn" in early modern studies. See, for example, Dan Brayton, Shakespeare's Ocean: An Ecocritical Exploration (Charlottesville: University of Virginia Press, 2012); and Steve Mentz, At the Bottom of Shakespeare's Ocean (London: Continuum, 2009).

12 See in particular Jonathan Goldberg, The Seeds of Things: Theorizing Sexuality and Materiality in Renaissance Representations (New York: Fordham University Press, 2009), and Jacques Lezra, Unspeakable Subjects: The Genealogy of the Event in Early Modern Europe (Stanford: Stanford University Press, 1997).

13 See Gordon Teskey, Allegory and Violence (Ithaca, NY: Cornell University Press, 1996).

14 Edmund Spenser, "Letter to Raleigh," in The Faerie Queene, ed. A. C. Hamilton, $2^{\text {nd }}$ ed. (London: Longman), 716.

15 Daniel Tiffany, Toy Medium: Materialism and Modern Lyric (Berkeley: University of California Press, 2000), 3.

16 Tiffany, Toy Medium, 3.

17 Ibid., 5. For a related discussion of framing technologies in Renaissance poetry, see Rayna Kalas, Frame, Glass, Verse: The Technology of Poetic Invention in the English Renaissance (Ithaca, NY: Cornell University Press, 2007).

18 James Kuzner, Open Subjects: English Renaissance Republicans, Modern Selfhoods and the Virtue of Vulnerability (Edinburgh: Edinburgh University Press, 2011), 39.

19 Reid Barbour, English Epicures and Stoics: Ancient Legacies in Early Stuart Culture (Amherst: The University of Massachusetts Press, 1998), 34.

20 Ibid., 35. Barbour's reference is to Bacon's De sapientia verterum ("Wisdom of the Ancients," 1609). 
21 Tiffany, Toy Medium, 5.

22 For a discussion of "cosmopolity", see Laurie Shannon, The Accommodated Animal.

23 Dan Brayton, Shakespeare's Ocean, 62-63.

24 Drew Daniel, The Melancholy Assemblage: Affect and Epistemology in the English Renaissance (New York: Fordham University Press, 2013), 5.

25 On the concept of "body without organs," see Gilles Deleuze and Félix Guattari, Anti-Oedipus: Capitalism and Schizophrenia, trans. Brian Massumi (Minneapolis: University of Minnesota Press, 1983). On Paster's usage of Deleuze and Guattari in relation to the body's liquid composition, see Humoring the Body, 1-24.

26 Foucault, "Friendship as a Way of Life," 135, 136.

27 See, for example, Jonathan Goldberg, Endlesse Worke: Spenser and the Structures of Discourse (Baltimore: Johns Hopkins University Press, 1981); James Kuzner, Open Subjects; Patricia Parker, Inescapable Romance: Studies in the Poetics of a Mode (Princeton: Princeton University Press, 1996); Melissa E. Sanchez, "Fantasies of Friendship in The Faerie Queene, Book IV," English Literary Renaissance 37 (2007): 250-73; and Kathryn Schwarz, Tough Love: Amazon Encounters in the English Renaissance (Durham: Duke University Press, 2000).

28 On the violence of epithalamion, see Melissa E. Sanchez, "Modesty or Comeliness': The Predicament of Reform Theology in Spenser's Amoretti and Epithalamion," Renascence 65 (2012): 5-24.

29 See Hamilton, ed. The Faerie Queene, 493.

30 See C. S. Lewis, The Allegory of Love (New York: Oxford University Press, 1971), 2.

31 On the subject of stone and animacy, see Jeffrey Jerome Cohen, Stone: An Ecology of the Inhuman (Minneapolis: University of Minnesota Press, 2015). For a related discussion of pain and the relational dynamics of vulnerability, see Joseph Campana, The Pain of Reformation: Spenser, Vulnerability, and the Ethics of Masculinity (New York: Fordham University Press, 2012). 